\title{
Fire Early Warning System Using Fire Sensors, Microcontroller, and SMS Gateway
}

\author{
Rizqi Sukma Kharisma ${ }^{1}$, Ardi Setiyansah ${ }^{2}$ \\ ${ }^{1,2}$ Department of Informatic, Universitas Amikom Yogyakarta, Yogyakarta, Indonesia \\ Email: ${ }^{1}$ sukma@amikom.ac.id, ${ }^{2}$ ardi.setiyansah@students.amikom.ac.id
}

\begin{abstract}
A fire disaster that does not save can certainly cause losses, both in the form of objects and casualties. This occurs for several reasons: late information obtained from the fire department or the owner's ignorance at the time of a fire. In this study, a fire early detection system was built using smoke, heat, and gas sensors based on an SMS gateway and an alarm. This system is used to provide information about fire detection as early as possible to protect against fire disasters. With this system, the potential and risk of fire can be reduced. This system is used to identify potential fires that occur in housing. Several experiments were carried out with fire simulations to get the reaction from the sensors used. Covers smoke testing, temperature testing, gas testing, and SMS message responses from various providers. This research produces a fire early warning system that provides SMS and alarm alerts.
\end{abstract}

Keywords-fire disasters, alarm, sensors, microcontroller, SMS gateway

\section{INTRODUCTION}

Fire disasters have increased from year to year; of course, fires can cause material loss and casualties [1]. In densely populated areas in Indonesia, quite a few fires often occur. From the statistical data in Indonesia, especially in Sleman Yogyakarta, house fires tend to increase. House fires can be caused by short circuits, gas stoves, and others [2]. Fire disasters that are not handled quickly certainly cause many losses, both in the form of casualties and loss of property and property. This happens because several factors include the result of the latest information obtained from the fire department and house fires when the owner is not at home [3][4][5]. There is a relationship between the delay in evacuation and the number of injured and dead victims, especially in fires in residential areas and hotels. Early indications of a fire such as the smell of smoke, seeing a fire are often ignored before a warning occurs, even though the initial indication is an opportunity for evacuation and selfrescue [6][7]. So we need a system capable of handling fire disasters. This system can provide information and early warning to building residents and officers directly.

Previous research used Arduino to detect and provide early warning when an earthquake occurs through alarms and alerts sent via cellphone [8]. Another study uses CCTV cameras to detect fires. In this study, an algorithm can detect the possibility of fire [9]. Research conducted by Hui Xu uses a GOWR sponge to detect fires. In this study, the GOWR sponge will trigger an alarm when a fire occurs [10]. Dubey's research provides fire early warning information by detecting heat, smoke, and using a flame sensor connected to the raspberry and GSM module [11]. In Park's research, he used heat sensors, $\mathrm{CO} 2$ sensors, and imaging to detect a possible fire. The data obtained is then processed in an algorithm to determine the fire's accuracy, and then the results are sent to firefighters [12]. Kadri made a study on early fire detection using smoke sensors and heat sensors, which were then connected wirelessly. The sensor will provide data to the raspberry to determine fire occurrence. Fire information can then be sent to officers [13]. In April research, fire detection uses smoke sensors and imaging using cameras. If the device detects a fire, the system will warn via alarm and SMS [14].

In this paper, a fire detection device prototype will be made using a smoke sensor, a gas sensor, and a heat sensor. If the intensity sensor exceeds the limit, the microcontroller will provide an early fire warning via buzzer alarm and SMS.

\section{METHODOLOGY}

\section{A. System Requirements}

Based on the functional requirements of the system, the fire early warning design must be able to meet the following functional requirements:

1. The device can detect temperature, gas, and smoke that exceed normal limits using sensors.

2. The sensor can transmit its detection data to ATEMega8.

3. ATEMega8 can process data originating from the detection sensor into information in the form of early detection.

4. ATEMega8 can send commands to Wavecom Modem in the form of detection information data coming from sensors.

5. Wavecom Modem can send information from ATEMega8 in the form of SMS Gateway to a cell phone (homeowner or fire department)

6. ATEMega8 can give commands to the buzzer if it detects an indication of fire.

The hardware used to build this device is as follows. ATEMega8 microcontroller is an 8-bit CMOS microcontroller with AVR RISC architecture, which has 8K Bytes In-System Programmable Flash. This low power consumption microcontroller is capable of executing instructions with a maximum speed of 16 MIPS at a frequency of $16 \mathrm{MHz}$ [15][16][17]. 
LM35 Heat Sensor is a change IC chip that functions to determine the temperature of an object or room in the form of an electrical quantity, or it can also be interpreted as an electronic component that functions to change the temperature received in changes in the amount of electricity. IC LM35 temperature sensor can change the temperature into a change in voltage at the output. The LM35 temperature sensor requires a DC voltage source of +5 volts and a DC consumption of $60 \mu \mathrm{A}$ in its weight [18][19][20].

TGS2600 is a smoke sensor for measuring contamination in the air. This sensor detects hydrogen and carbon monoxide gas. This sensor works on $5 \mathrm{v}$ voltage with a resistance of $10 \mathrm{KW}-90 \mathrm{KW}$ in the air. [21][22][23].

Gas Sensor MQ-6 is a sensor that can handle gas leaks of Liquefied petroleum gas (LPG). The output produced by this sensor is in the form of analog and digital signals. This sensor also requires a direct current (DC) voltage of 5 volts. Has high sensitivity and fast response time in handling LPG gas [24][25][26].

Wavecom M 1306b Q2403A GSM is a GSM / GPRS modem that is used for SMS gateway and internet. This device uses a SIM card, which can be easily operated using a service provider [27][28][29][30].

\section{B. Block Diagram}

The design to be made is divided into three main blocks, namely the input block, the process block, and the output block. Fig. 1 shows a block diagram.

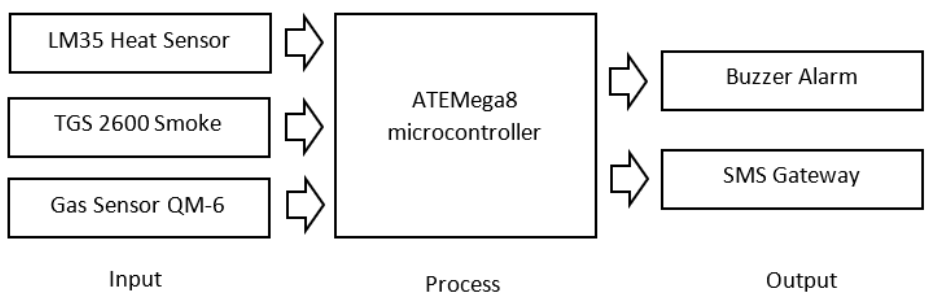

Fig. 1. Block Diagram

The following is an explanation of Fig. 1:

1. The input block is the part that gets the initial data. In this block, there is an LM35 heat/temperature sensor, a TGS 2600 smoke sensor, and a QM-6 Gas Sensor.

2. In the process, the block consists of procedures, logic, and mathematical models that will manipulate input data and data stored in the database in a specific way to produce the desired output. In the process block, there is an ATEMega8 Microcontroller.

3. The output block is the result of processing data into information. The output block consists of the Buzzer/address system and SMS Gateway.

\section{Schematic, PCB Layout, and Prototype}

Fig. 2 shows a schematic diagram of a fire detection device. Fig. 3 shows the PCB circuit layout design. Fig. 4 shows a Prototype of a fire detection device.

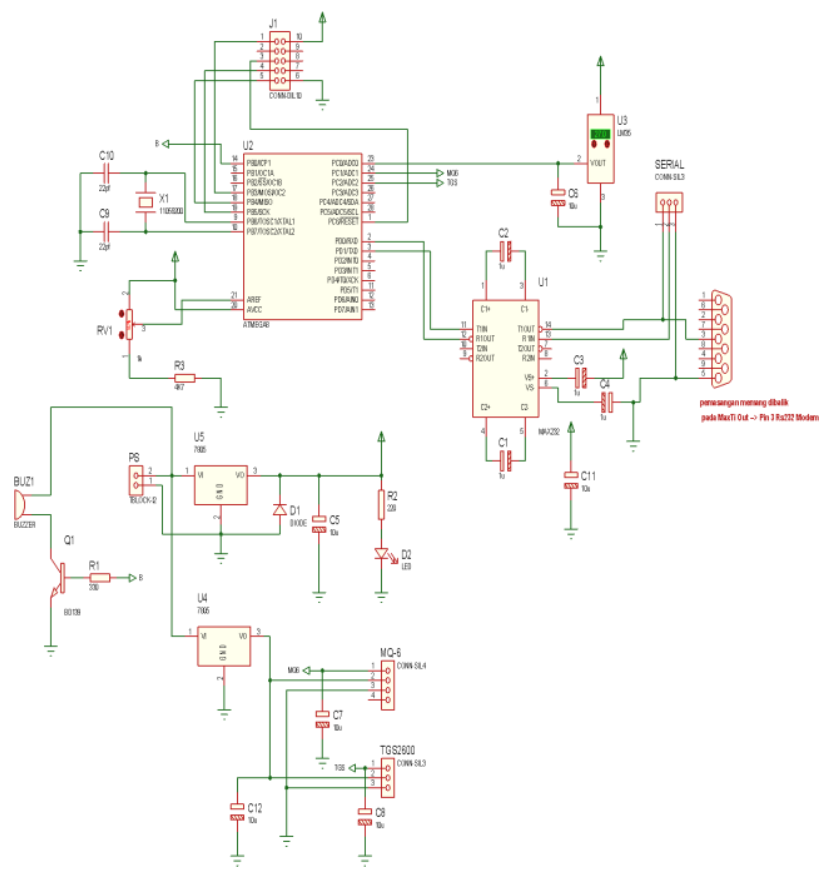

Fig. 2. Schematic Diagram of a Fire Detection Device

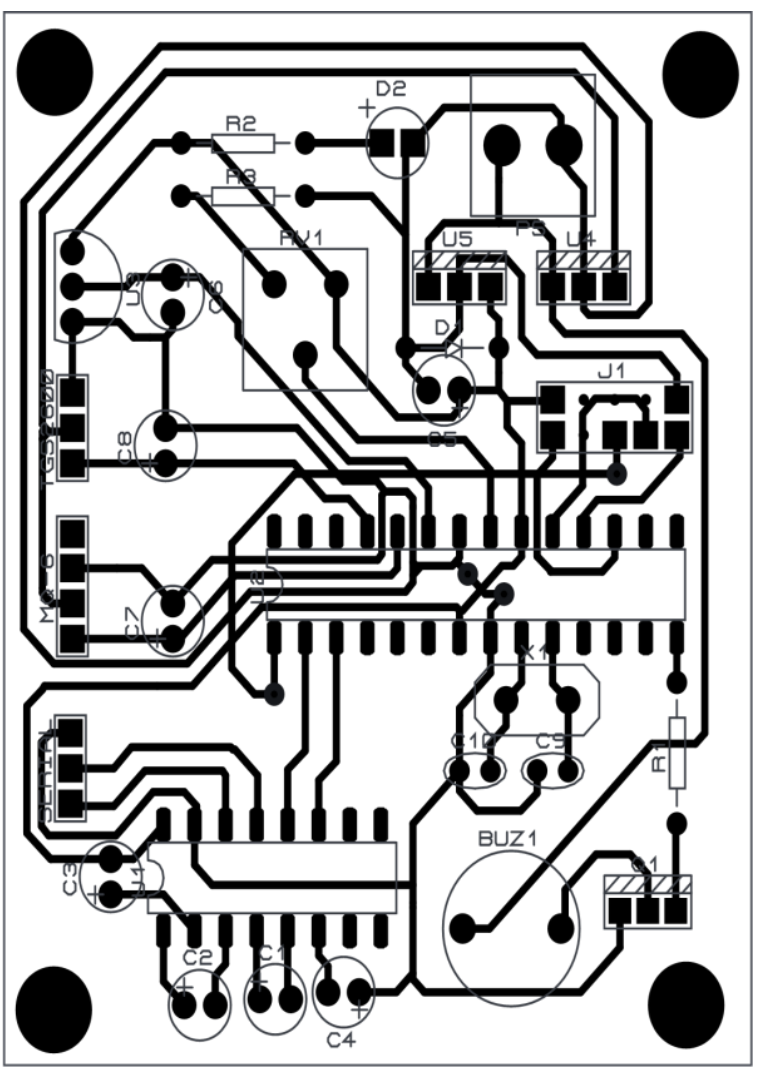

Fig. 3. PCB Circuit Layout Design 


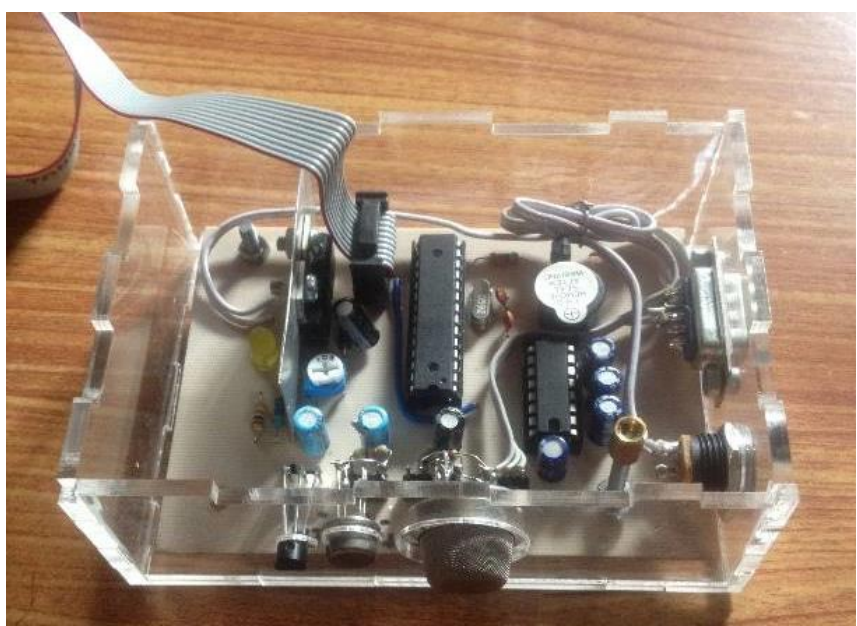

Fig. 4. A prototype of a Fire Detection Device

\section{RESULTS AND DISCUSSION}

Testing was conducted using several GSM providers to obtain parameters for the modem's length of time to send an SMS to the user's cell phone. Table I and Fig. 5 show the GSM SMS test results.

TABLE I. TESTING SMS

\begin{tabular}{|c|l|c|c|}
\hline $\begin{array}{c}\text { Testing } \\
\text { Number }\end{array}$ & Provider GSM & $\begin{array}{c}\text { Respond Time } \\
\text { (Second) }\end{array}$ & Result \\
\hline 1 & Provider A & 14 & Received \\
\hline 2 & Provider B & 7 & Received \\
\hline 3 & Provider C & 13 & Received \\
\hline 4 & Provider D & 5 & Received \\
\hline 5 & Provider E & 11 & Received \\
\hline
\end{tabular}

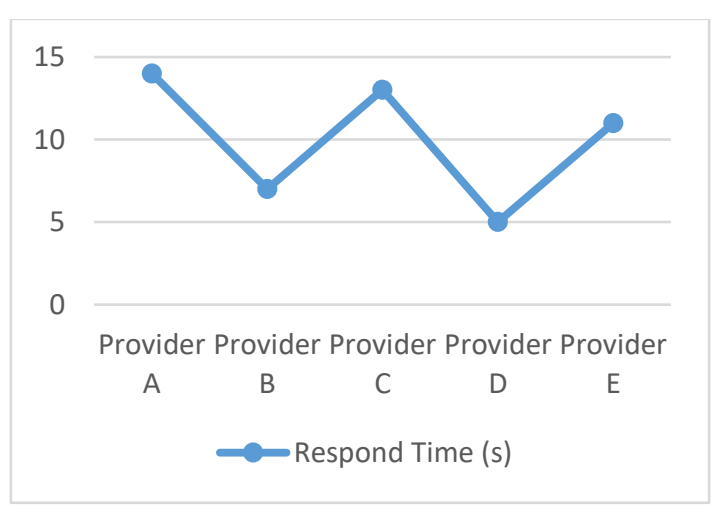

Fig. 5. Obtained Respond Time Providers

From this test, shows that provider D has the fastest message delivery response speed.

It was testing the LM35 Temperature Sensor by heating the temperature around the sensor. This sensor test is done to find out any temperature around the room, especially when a fire occurs so that the voltage on this temperature sensor will be compared with the potentiometer voltage, which is set to determine the minimum temperature limit that is feasible to signal a fire hazard to the temperature sensor.
In the observation data, the voltage on the potentiometer (point A) becomes $0.60 \mathrm{~V}$. From the observation data at point $\mathrm{B}$, and it is found that the voltage starts from $0.296 \mathrm{~V}$ to 1.315 $\mathrm{V}$ (when the temperature starts to heat up to the maximum) sequentially, then for measuring the difference of 5 each data. Table II shows the test results of the LM35 sensor.

TABLE II. TESTING THE LM35 TEMPERATURE SENSOR

\begin{tabular}{|c|c|c|c|c|}
\hline $\begin{array}{c}\mathbf{V} \\
\text { potentiometer } \\
\text { / No-inverting } \\
(\mathbf{A})\end{array}$ & $\begin{array}{c}\text { Veut } \\
\text { Sensor / } \\
\mathbf{V} \\
\text { invertin } \\
\mathbf{g}(\mathbf{B})\end{array}$ & $\begin{array}{c}\text { Temper } \\
\text { ature } \\
\mathbf{(} \mathbf{c})\end{array}$ & $\begin{array}{c}\mathbf{V} \\
\text { Comparator } \\
\text { out (C) }\end{array}$ & Indicator \\
\hline $0.60 \mathrm{~V}$ & $0.296 \mathrm{~V}$ & 29.6 & $4.96 \mathrm{~V}$ & Off \\
\hline $0.60 \mathrm{~V}$ & $0.353 \mathrm{~V}$ & 35.6 & $4.96 \mathrm{~V}$ & Off \\
\hline $0.60 \mathrm{~V}$ & $0.421 \mathrm{~V}$ & 42.1 & $4.96 \mathrm{~V}$ & Off \\
\hline $0.60 \mathrm{~V}$ & $0.462 \mathrm{~V}$ & 46.2 & $4.96 \mathrm{~V}$ & Off \\
\hline $0.60 \mathrm{~V}$ & $0.532 \mathrm{~V}$ & 53.2 & $4.96 \mathrm{~V}$ & Off \\
\hline $0.60 \mathrm{~V}$ & $0.624 \mathrm{~V}$ & 62.4 & $0.034 \mathrm{~V}$ & On \\
\hline $0.60 \mathrm{~V}$ & $0.673 \mathrm{~V}$ & 67.3 & $0.034 \mathrm{~V}$ & On \\
\hline $0.60 \mathrm{~V}$ & $0.701 \mathrm{~V}$ & 70.1 & $0.034 \mathrm{~V}$ & On \\
\hline
\end{tabular}

From this test, it shows if the sensor detects heat above $53.2^{\circ} \mathrm{c}$, then the $\mathrm{V}$ Comparator out indicates a voltage of $0.034 \mathrm{~V}$ which triggers the indicator to turn on.

Gas sensor testing QM-6 is carried out to see the effect of gas detection distance on the length of time the indicator turns on. The QM-6 Gas Sensor will detect dangerous gas levels if the detected gas level is more than 900ppm (> 900ppm). If the gas level is below 900ppm (<900ppm), the sensor detects normal gas levels. Gas sensor testing uses liquefied butane gas. Table III shows the results of testing the QM-6 sensor. In Fig. 6 Obtained Relationship Between Distance and Response Time QM-6 Gas Sensor

TABLE III. TESTING THE QM-6 GAS SENSOR

\begin{tabular}{|c|c|c|}
\hline $\begin{array}{c}\text { Testing } \\
\text { Number }\end{array}$ & Distance (cm) & $\begin{array}{c}\text { Respond time } \\
\text { (second) }\end{array}$ \\
\hline 1 & 5 & 3 \\
\hline 2 & 7 & 6 \\
\hline 3 & 10 & 11 \\
\hline 4 & 15 & 18 \\
\hline 5 & 20 & 28 \\
\hline
\end{tabular}




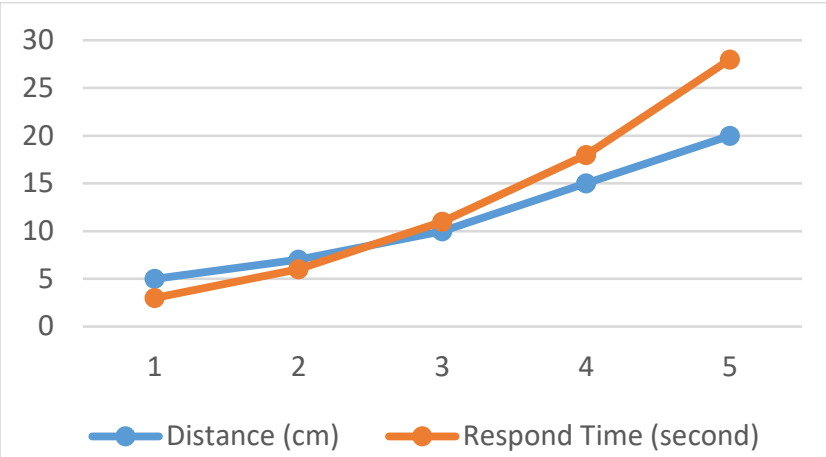

Fig. 6. Obtained Relationship Between Distance and Response Time QM6 Gas Sensor

In testing, the TGS 2600 smoke sensor was carried out to see the effect of the smoke detection distance on the length of time the indicator was on. The TGS 2600 smoke sensor will detect dangerous smoke levels if the detected smoke level is more than 900ppm (> 900ppm). If the smoke level is below 900ppm $(<900 \mathrm{ppm})$, the sensor detects normal smoke levels.

TABLE IV. RESULT

\begin{tabular}{|c|c|c|c|c|c|}
\hline \multirow{2}{*}{$\begin{array}{c}\text { Testing } \\
\text { Number }\end{array}$} & \multirow{2}{*}{ Distance (cm) } & \multicolumn{3}{|c|}{ Smoke Level } & \multirow{2}{*}{$\begin{array}{c}\text { Respond } \\
\text { Time }\end{array}$} \\
\hline & & Low & Mid & Hight & \\
\hline 1 & 4 & & & $\checkmark$ & 3 \\
\hline 2 & 6 & & & $\checkmark$ & 7 \\
\hline 3 & 13 & & $\checkmark$ & & 19 \\
\hline 4 & 15 & $\checkmark$ & & & 20 \\
\hline 5 & 20 & $\checkmark$ & & & 29 \\
\hline
\end{tabular}

\section{CONCLUSION}

From this paper, the functional testing of the designed prototype has been tested. The test is carried out in a way that is as ideal as possible following the near-real situation. From the results obtained, this system is running successfully. The response of sending SMS based on sensor input goes as expected.

The development of this system can add better sensors and server features for a wider range of IoT needs. Processing results from sensors can be further processed by immersing artificial intelligence or learning machines.

\section{REFERENCES}

[1] S. Strydom and M. J. Savage, "A spatio-temporal analysis of fires in the Southern African Development Community region," Nat. Hazards, vol. 92, no. 3, pp. 1617-1632, 2018.

[2] M. R. Suryoputro, F. A. Buana, A. D. Sari, and F. I. Rahmillah, "Active and passive fire protection system in academic building $\mathrm{KH}$. Mas Mansur, Islamic University of Indonesia," MATEC Web Conf., vol. 154 , pp. $0-5,2018$

[3] C. E. Marrion, "More effectively addressing fire/disaster challenges to protect our cultural heritage," J. Cult. Herit., vol. 20, pp. 746-749, 2016.

[4] H. Ando et al., "Aerial Hose Type Robot by Water Jet for Fire Fighting," IEEE Robot. Autom. Lett., vol. 3, no. 2, pp. 1128-1135, 2018 .

[5] W. Nurul, A. Putri, F. T. Maharani, and U. Q. Karima, "Analysis Of The Suitability Of Fire Handling With Active Fire Protection In Yaperjasa Senior High School In 2020," Heal. Saf. Environ. J., vol. 1 , no. $1,2020$.

[6] M. Kobes, I. Helsloot, B. de Vries, and J. G. Post, "Building safety and human behaviour in fire: A literature review," Fire Saf. J., vol. 45 , no. 1, pp. 1-11, 2010.

[7] V. Sherstjuk, M. Zharikova, and I. Sokol, "Forest Fire-Fighting Monitoring System Based on UAV Team and Remote Sensing," 2018 IEEE 38th Int. Conf. Electron. Nanotechnology, ELNANO 2018 Proc., vol. 7, pp. 663-668, 2018.

[8] A. Beltran Jr, K. J. Dizon, K. Nones, R. L. Salanguit, J. Bhie Santos, and J. Rei Santos, "Arduino-based Disaster Management System," J. Robot. Control, vol. 2, no. 1, pp. 24-28, 2020.

[9] K. Muhammad, J. Ahmad, and S. W. Baik, "Early fire detection using convolutional neural networks during surveillance for effective disaster management," Neurocomputing, vol. 288, pp. 30-42, 2018.

[10] H. Xu et al., "Temperature-triggered sensitive resistance transition of graphene oxide wide-ribbons wrapped sponge for fire ultrafast detecting and early warning," J. Hazard. Mater., vol. 363, pp. 286294, 2019

[11] V. Dubey, P. Kumar, and N. Chauhan, Forest Fire Detection System Using IoT and Artificial Neural Network, vol. 55. Springer Singapore, 2019.

[12] J. H. Park, S. Lee, S. Yun, H. Kim, and W. T. Kim, "Dependable fire detection system with multifunctional artificial intelligence framework," Sensors (Switzerland), vol. 19, no. 9, 2019.

[13] B. Kadri, B. Bouyeddou, and D. Moussaoui, "Early Fire Detection System Using Wireless Sensor Networks," Proc. 2018 Int. Conf. Appl. Smart Syst. ICASS 2018, no. November, pp. 1-4, 2019.

[14] A. Jadon, M. Omama, A. Varshney, M. S. Ansari, and R. Sharma, "FireNet: A Specialized Lightweight Fire \& Smoke Detection Model for Real-Time IoT Applications," 2019.

[15] N. Evalina and H. A Azis, "Implementation and design gas leakage detection system using ATMega8 microcontroller," IOP Conf. Ser. Mater. Sci. Eng., vol. 821, no. 1, 2020.

[16] A. Latif and K. Supriyadi, "Temperature and Humidity Observation System in ATmega8 Microcontroller-Based Homes," IOP Conf. Ser. Mater. Sci. Eng., vol. 835, no. 1, 2020.

[17] T. P. Tunggal, A. W. Apriandi, J. E. Poetro, E. T.Helmy, and F. Waseel, "Prototype of Hand Dryer with Ultraviolet Light Using ATMega8," J. Robot. Control, vol. 1, no. 1, pp. 18-21, 2020.

[18] V. S. Chin et al., "Development of Low-Cost Temperature Sensing Fan using Mapping Method on Arduino Uno and LM35 Temperature Sensor," pp. 1-12, 2019.

[19] M. Ramos, "Characterization of LM35 Sensor for Temperature Sensing of Concrete," Lect. Notes Eng. Comput. Sci., vol. 2228, pp. 760-764, 2017.

[20] P. D. Prasetyo Adi and A. Kitagawa, "Performance evaluation WPAN of RN-42 bluetooth based (802.15.1) for sending the multi-sensor LM35 data temperature and raspBerry pi 3 Model B for the database and internet gateway," Int. J. Adv. Comput. Sci. Appl., vol. 9, no. 12, pp. 612-620, 2018.

[21] W. Eugster, J. Laundre, J. Eugster, and G. W. Kling, "Long-term reliability of the Figaro TGS 2600 solid-state methane sensor under low-Arctic conditions at Toolik Lake, Alaska," Atmos. Meas. Tech., vol. 13, no. 5, pp. 2681-2695, 2020.

[22] J. Palacín et al., "Application of an array of metal-oxide semiconductor gas sensors in an assistant personal robot for early gas leak detection," Sensors (Switzerland), vol. 19, no. 9, pp. 1-16, 2019.

[23] A. Collier-Oxandale et al., "Assessing a low-cost methane sensor quantification system for use in complex rural and urban environments," Atmos. Meas. Tech., vol. 11, no. 6, pp. 3569-3594, 2018.

[24] K. Tamizharasan, V; Ravichandran, T; Sowndariya, M; Sandeep, R; Saravanavel, "Gas Level Detection and Automatic Booking Using IOT," 2019 5th Int. Conf. Adv. Comput. Commun. Syst., pp. 922925, 2019.

[25] M. Miftakul Amin, M. Azel Aji Nugratama, A. Maseleno, M. Huda, and K. A. Jasmi, "Design of cigarette disposal blower and automatic freshner using MQ-5 sensor based on atmega 8535 microcontroller," Int. J. Eng. Technol., vol. 7, no. 3, pp. 1108-1113, 2018.

[26] E. Fatkiyah, D. Persada, and D. Andayati, "Early Detection of Leaks on Gas Cylinders Using Arduino Based MQ-6 Sensors," J. Phys. Conf. Ser., vol. 1413, no. 1, 2019.

[27] M. R. Z. Fajar, S. Hadiyoso, and A. Rizal, "An interfacing digital blood pressure meter with arduino-GSM module for real-time monitoring," ICCREC 2017 - 2017 Int. Conf. Control. Electron. Renew. Energy, Commun. Proc., vol. 2017-Janua, pp. 98-102, 2017.

[28] A. Saryanto and A. B. Setiawan, "BUILDING SYSTEM OF PERSONNEL MOVEMENT USING GLOBAL POSITIONING SYSTEM ( GPS ) DESIGN,” no. August, pp. 978-979, 2017. 
[29] A. Rghioui, A. Naja, and A. Oumnad, "Diabetic Patients Monitoring and Data Classification Using IoT Application," 2020 Int. Conf. Electr. Inf. Technol. ICEIT 2020, 2020.

[30] U. Katu, S. Pallu, M. Tola, and Z. Hasanuddin, "Flood early warning system and distribution of information communication using radio link,” Int. J. Civ. Eng. Technol., vol. 8, no. 7, pp. 1255-1262, 2017. 